\title{
The Effect of Leadership Style and Work Motivation on Work Productivity for Teachers in All State Junior High Schools of Surakarta
}

\author{
Baidi $^{1, *}$, Heldy Ramadhan Putra P. ${ }^{1}$, Junaidah $^{2}$ \\ ${ }^{1}$ Department of Educational Management, Faculty of Tarbiyah Science, The State Islamic Institute of Surakarta, Indonesia \\ ${ }^{2}$ Department of Educational Management, Faculty of Tarbiyah Science, Raden Intan State Islamic University, Indonesia
}

Received December 9, 2019; Revised February 10, 2020; Accepted February 25, 2020

Copyright $\odot 2020$ by authors, all rights reserved. Authors agree that this article remains permanently open access under the terms of the Creative Commons Attribution License 4.0 International License

\begin{abstract}
The background of this study is the low productivity of teachers in school. This is influenced by several things, one of which is the lack of teacher preparation in preparing the learning process in class, and there are still many school programs that have not been completed in accordance with the specified targets. The role of the principal as a leader is very important to increase teacher productivity in school. The purposes of this study are to determine the effect of; (1) leadership style on work productivity for teachers in all State Junior High Schools of Surakarta, (2) work motivation on work productivity for teachers in all State Junior High Schools of Surakarta. This study used a quantitative approach with a survey method. The sample of this study was 300 teachers throughout Surakarta gathered from 27 State Junior High schools which were randomly selected. The results of this study indicate that; (1) leadership style has a direct positive effect on teachers' productivity in all State Junior High Schools of Surakarta, (2) work motivation has a direct positive effect on teachers' productivity in all State Junior High Schools of Surakarta, and (3) leadership style has a direct positive effect on teachers' work motivation in all State Junior High Schools of Surakarta. If it is viewed from the results of the path analysis, the conclusion of this study is work motivation being the most influential variable on increasing teachers' productivity in State Junior High School of Surakarta. Thus, this research is important to be recommended to educational policy makers in Surakarta as a reference in increasing work motivation of teachers in school.
\end{abstract}

Keywords Work Productivity, Leadership Style, Work Motivation

\section{Introduction}

School productivity is the result of every learning activity, both in the class and outside the class. This cannot be separated from the role of the teacher in the school. The teacher is an actor in creating a conducive situation and climate in the school. By refering to the changes that occur and the demands of the task at hand, there are a number of problems faced by the teacher, among of them caused by the changes in the paradigm of attitude and behavior. It should be recognized that the changes cannot always be accepted or run smoothly. There are some principals of Junior High school still applying the old paradigm and are ready to face the changes or demands faced. Based on interviews with supervisor coordinator of Surakarta, the data shows that the low productivity of Junior High School teachers is indicated by: (1) There are still many teachers who carry out their duties without proper preparation and planning, such as; learning planning, carrying out learning activities and learning process assessment activities. (2) There is a tendency for teachers to ignore the additional assignments given by the principal because they assume that the task is the duty of the principal. (3) The teachers are often unable to complete the entire program set by the school. (4) The teachers are less creative and innovative in applying the learning process in class.

There are several factors that influence teachers' productivity, one of which is the principal's leadership style. In the current era of decentralization, junior high school principals must take the initiative to lead their schools. Top down leadership experience should immediately be abandoned. Instructive and top-down leadership of principals have indeed been practiced in most schools for a long time when the centralistic era was still ongoing. Some schooling education issues as a result 
of instructive and top down leadership models can be mentioned, among others are: the target achievement system for the curriculum, the number of graduation targets, the student graduation formula, and the design of a school quality improvement project that must be associated with increased National Examination results (UN) instructively. The Principals in carrying out their duties are always bound by operational guidelines and technical guidelines. The negative impact of the model above is the closure of schools in the process of renewal and innovation.

The reality in the field is indeed diverse, not all junior high school principals apply leadership that is in line with the global demands and decentralization of education. Not all principals apply the leadership they seek to avoid creating a pattern of relations with teachers who rely solely on power, and begin to promote functional cooperation. There is even a principal still acting as a one-man show and not emphasizing on corporate cooperation, creates a less harmonious work atmosphere, and conditions that make teachers less confident.

Whereas in the research conducted by Ade Parluangan, 2016 [1], it reveals that "according to the results of this study that the leadership style of a manager of high contributed to the level of labor productivity, by why need to be considered by the managers to always provide a positive role model and sporty subordinates, and able to provide the motivation so that the level of labor productivity is expected to increase.

Beside leadership, other factors that influence productivity are motivations. Work motivation is something that can generate enthusiasm and encouragement to work. Motivation can be from internal or external sources. Every organization in an effort to achieve the goals is required to carry out management of Human Resources which is a very important aspect of all available resources in the organization. Because it is caused by every human being having the ability to grow and develop in accordance with the situations and conditions in which an employee works, there is a need to encourage motivation and enthusiasm through various approaches that lead to the growth of good motivation to increase work productivity. This is in line with the research done by Chukwuma and Obiefuna Okafor, 2014 [2], stating that "the researcher therefore conclude from his findings that the effect of motivation on employee productivity is of paramount important to the organization. In order to meet up with the current dynamic rate of the business trends, the management of the manufacturing firms in Nnewi should try as much as possible to adopt good and positive motivational techniques to increase the moral of the workers towards productivity and performance".

\section{Theoretical Foundations}

\subsection{The Effect of Leadership Style on Work Productivity}

High work productivity is one of the purposes of school organization achieved. Whether these goals are achieved or not depends on the human resources available at the school, because human resources are dynamic factors capable of determining the progress of a school organization, an organization is referred to be progressing or successful if the organization has a high level of productivity.

Leadership is one of the factors that can affect work productivity, as stated by Slocum, 2007 [3],"some studies suggest that a leader who emphasizes initiating structure generally improves productivity, at least in the short run".

\subsection{The Effect of Work Motivation on Work Productivity}

Productivity is technically an understanding of production efficiency, especially in the use of science and technology. Productivity is formulated as the ratio of output to input. Work productivity will be achieved if employees of an organization have high motivation to achieve their goals. Work motivation that is owned by an employee will affect the level of achievement of productivity, whether it is appropriate or still below the standard goals. Scott G. Isaksen, 1998 [4], states that "within this diagram, cognitive style would have the most influence within the frame of psychological and organizational processes". Organization and psychological processes, problem solving, decision making, learning, motivation, communication, effects on quality, creativity, productivity, well being, job satisfaction".

\subsection{The Effect of Leadership Style on Work Motivation}

Griffin, 2010 [5], states that, "as a process, leadership involves the use of noncoercive influence to direct and coordinate the activities of group members to meet a goal. Influence, a common element of both perspectives, is the ability to effect the perceptions, beliefs, attitudes, motivation, and behavior others".

\section{Literature Review}

\subsection{Work Productivity}

An organization willing to grow and develop always strives to improve work productivity. As a system, an organization will pay attention to inputs, processes and outputs, including management systems, functional systems and operational systems. It is not a new thing if work productivity will determine the progress of an organization. That is, a system can be said to be 
productive if the input processed is less to produce greater output. Of course there are many ways used to measure the high and the low of productivity. According to [6], work productivity is "productivity, at its simplest, is a ratio that compares units of outputs with units of inputs, often against a predetermined standard. If more outputs can be produced from the same amount of inputs, productivity is improved. Or if fewer inputs can be used to produce the same amount of outputs, productivity has increased".

Meanwhile [7], define work productivity as, "productivity is the amount of goods or services produced divided by the inputs needed to generate that output. Organizations and individual work units want to be productive. They want to produce the most goods and services using the least amount of inputs. Output is measure by the sales revenue an organization receives when goods are sold. Input is measured by the costs of acquiring and transforming resousces into outputs".

Productivity according to Koontz, H. Weihrich in the journal of Janjua Najam, 2016 [16], is stated that, "productivity is an output input ratio within a time period with due consideration for quality". In line with this, Zaenal Mustafa Elqadri, 2015 [17], argues that; "productivity is a concept that describes the relationship between the result (the amount of goods and services), the source (the amount of labor, capital, land, energy, and so on), which are used to produce those result.

\subsection{Leadership Style}

Leadership is the applied science of the social sciences, because its principles and formulations are expected to bring benefits to human welfare. Appropriate leadership in leading an institution or organization requires expertise. Leading an organization is very important, because the leadership applied will affect the performance and character of its subordinates.

Phillips, (2012) [8], defines leadership as, "leadership means guiding and influencing others to work willingly toward the leader's objectives. Leaders set team goals, train team members, provide feedback, manage resources, support the team, and perform a variety of other roles. Leadership can have positive and negative effects in organizations".

Then Griffin, 2010 [5], argues leadership as, "leadership is both a process and property. As a process, leadership involves the use of noncoercive influence to direct and coordinate the activities of group members to meet a goal. As a property, leadership is a set of characteristics attributed to those who are perceived to use such influence successfully".

Meanwhile, Robbins, 2013[9], also argues about leadership as, "leadership is what leaders do. It's a process of leading a group and influencing that group to achieve it's goals. Exerciing leadership does not require that one be in a formal leadership position. Three important variabels present in all leadership situations are people, task, and environment".

According to Gibson, Ivancevich, Donnely, Konopaske, 2006 [6], leadership is "as the process of influencing others to facilitate the attainment of organizationally relevant goals". Leadership as a process to influence the others to facilitate the achievement of relevant organizational purposes. Gibson, et. al., [6] also states leadership style as follows, "hersey and Blanchard uses the Ohio State University (OSU) studies to further develop four leadership styles available to managers: a) Telling, the leader defines the roles needed to do the job and tells followers what, where, how, and when to do the task. b) Selling, the leader provides followers with structured instructions, but it also supportive. c) Participating, the leader and followers share in decisions about how best to complete a high-quality job. d) Delegating, the leader provides little specific, close dorection or personal support to followers".

\subsection{Work Motivation}

Currie, 1997 [10], states, "work motivation, therefore is the willingness to apply such efforts towards the achievement of the organization's goals, also at the same time, an individual need is satisfied". Then Robbins, 2013 [9], defines work motivation as, "motivation refers to the process by which a person's efforts are energized, directed, and sustained toward attaining a goal. This definition has three key elements: energy, direction, and persistence". Meawhile Howard, 1989 [18], states that, "work motivation typically has been describe within the organizational behavior literature as the set of psychological processes thatcause the initiation, direction, intensity, and persistence of behavior".

Work motivation according to Richard, 2003 [11], "work motivation is the process that initiates and maintains goal directed perfomance. It energizes our thinking, fuels our enthusiasm and colors our positive and negative emotional reactions to work and life. Motivation generates the mental efford that drives us to apply our konwledge and skills. Without motivation, even the most capable person will refuse to work hard".

Newstrom, 2007 [6], expalains that, "work motivation is the set of internal and external forces that cause an employee to choose a course of action and engage in certain behaviors. Ideally, these behaviors will be directed at the achievement of a organizational goal. Work motivation is a complex combination of psychological forces within each person, and employers are vitally interested in three elements of it; direction and focus of the behavior, level of the effort provided, and persistence of the behavior".

\section{Methodology}

This research used quantitative approach applying 
survey method. Gay, Mills, and Airasian, 2011 [12], describes survey research as "survey research involves collecting data to test hypotheses or to answer quetions about people's opinions on some topic or issue. A Survey is an instrument to collect data that describe one or more characteristics of a spesific population." The influence between variables in this study was analyzed using path analysis techniques.

\subsection{Research Instrument}

Productivity is the work achieved by the teacher in a certain time, with the following indicators; (1) achieving work standards, (2) work efficiency, (3) work timeliness, (4) work quality.

Leadership style is the principal's actions influencing group members in an effort to achieve shared goals, with the following indicators; (1) setting work goals, (2) providing assistance, (3) facilitating work implementation, and (4) delegating work tasks.

Work motivation is an encouragement arising in one's self that drives and directs his behavior to carry out work and other activities in achieving the goals set, with the following indicators; (1) seriousness at work, (2) enthusiasm at work, (3) initiative at work, (4) achievement.

\subsection{Validiy and Reliability}

Table 1. Result of Validity Test

\begin{tabular}{|c|c|c|c|}
\hline Instrument & N & Valid Item & Invalid Item \\
\hline Productivity & 35 & 32 & 3 \\
\hline Leadership style & 35 & 30 & 5 \\
\hline Work motivation & 35 & 31 & 4 \\
\hline
\end{tabular}

Table 2. Result of Reliability Calculations

\begin{tabular}{|c|c|c|c|}
\hline Instrument & Valid Item & Alpha Value & Note \\
\hline Productivity & 32 & 0,954 & Reliable \\
\hline Leadership style & 30 & 0,966 & Reliable \\
\hline Work motivation & 31 & 0,952 & Reliable \\
\hline
\end{tabular}

\section{Findings}

\subsection{The Direct Effect of Leadership Style $\left(X_{1}\right)$ on Work Productivity (Y)}

From the results of the calculation of path coefficients, it is obtained the path of positive direct influence of leadership style on work productivity, $P_{y 1}$ is 0,138 . The value of $t_{\text {count }}=2,065$, while the value of $t_{\text {table }}$ is on significant level of $\propto(0,05)=1,97$. Because of $t_{\text {count }}>$ $t_{\text {table }}$, so that $H_{0}$ is rejected and $H_{1}$ is accepted. Thus, it can be concluded that leadership style has direct influence on work productivity.

\subsection{The Direct Effect of Work Motivation $\left(X_{2}\right)$ on Work Productivity (Y)}

From the results of the calculation of path coefficients, it is obtained the path of positive direct influence of work motivation on work productivity, $P_{y 1}$ is 0,139 . The value of $t_{\text {count }}=2,014$, while the value of $t_{\text {table }}$ is on significant level of $\propto(0,05)=1,97$. Because of $t_{\text {count }}>t_{\text {table }}$, so that $H_{0}$ is rejected and $H_{1}$ is accepted. Thus, it can be concluded that work motivation has direct influence on work productivity.

\subsection{The Direct Effect of Leadership Style $\left(X_{1}\right)$ on Work Motivation $\left(\mathbf{X}_{2}\right)$}

From the results of the calculation of path coefficients, it is obtained the path of positive direct influence of leadership style $\left(\mathrm{X}_{1}\right)$ on work motivation, $\mathrm{P}_{21}$ is 0,579 . The value of $t_{\text {count }}=12,37$, while the value of $t_{\text {table }}$ is on significant level of $\propto(0,05)=1,97$. Because of $t_{\text {count }}>t_{\text {table }}$, so that $\mathrm{H}_{0}$ is rejected and $\mathrm{H}_{1}$ is accepted. Thus, it can be concluded that leadership has direct influence on work motivation.

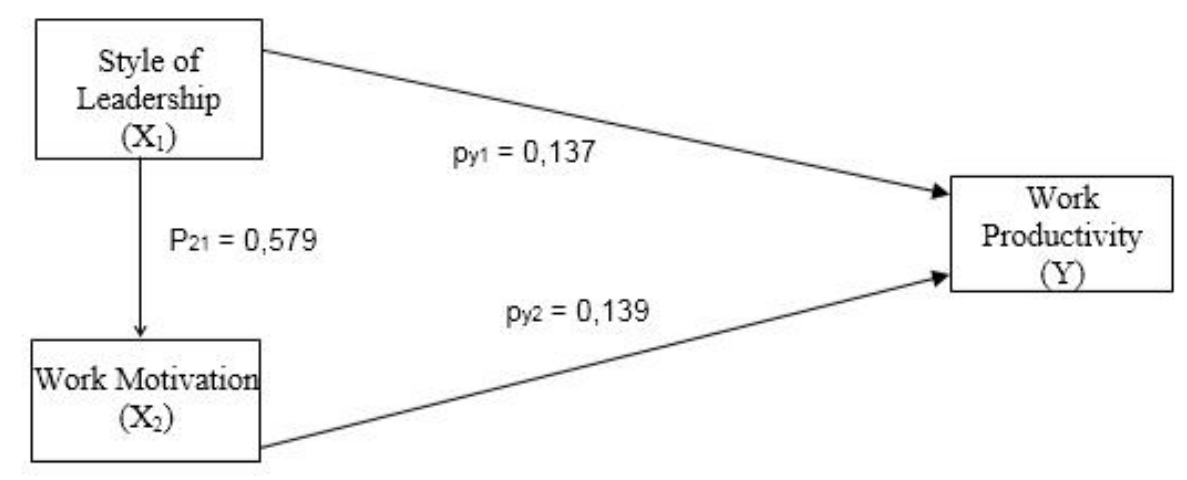

Figure 1. Structural Model of Inter-Variable Influence 


\section{Discussion}

The results obtained after conducting path analysis are used as a basis in answering hypotheses and drawing conclusions in this study. Explanation of the answers to these hypotheses can be described as follows:

\subsection{The Direct Positive Effect of Leadership Style on Work Productivity}

The testing of the first hypothesis of this study is that leadership style has a direct positive effect on work productivity. The results of this analysis prove that a good leadership style will have an impact on increasing work productivity. Such results can be understood, because work productivity is a result formed from the accumulation of various factors. Work productivity of an employee in an organization, can be assessed from the performance in accordance with his duties based on work standards set by the organization.

This research finding is in line with theory of Gibson, 2006 [6], stating that, "A leader can make a difference in measures of organizational effectiveness: production, efficiency, quality, flexibility, satisfaction, competitiveness, and development. However, shcolars and practitioners of leadership have a long way to go before they will be able to measure the exact degree of difference that leaders can and do make in any organization". This research is also in line with the theory concept stated by Robbins, 2013 [13], "physical abilities, the capacity to do task that demand stamina, dexterity, strength, and similar characteristics". Based on those explanations, these research results support previous theories and research proving that leadership style has positive influence on work productivity.

\subsection{The Direct Positive Effect of Work Motivation on Work Productivity}

The testing of the second hypothesis of this study is that work motivation has a direct positive effect on work productivity. Based on the findings, it can be concluded that work productivity is positively and directly influenced by work motivation. The increase of work motivation result in the increase of work productivity.

Work motivation is an impulse that arises in a person who moves and directs his behavior to work and do other activities in achieving predetermined goals with indicators: determination of work goals, sincerity in work, enthusiasm in work, initiative in work, achievement.

In organizations, work motivation is an important thing, among the success factors of the organization in reaching its goals. Work motivation is an attitude that can provide with a spirit of driving or work encouragement, action or business. The greater work motivation of a person has, the more effective and efficient implementation of work productivity will be resolved.

This research result is in line with the research done by Chukwuma dan Obiefuna Okafor, 2014 [2], which concludes, "the researcher therefore conclude from his findings that the effect of motivation on employee productivity is of paramount important to the organization. In order to meet up with the current dynamic rate of the business trends, the management of the manufacturing firms in Nnewi should try as much as possible to adopt good and positive motivational techniques to increase the moral of the workers towards productivity and performance".

Based on the explanation above, the results of this study reinforce the theories and the previous research that prove that there is a positive direct influence of work motivation on work productivity.

\subsection{The Direct Positive Effect of Leadership Style on Work Motivation}

The analysis results of the third hypothesis provide findings that the leadership style has a direct positive effect on work motivation. Based on these findings, it can be concluded that work motivation is directly influenced positively by leadership style. The increase of leadership style will lead to the increase of work motivation. The results of this study are in line with the opinions of some experts, among others are Leslie W. Rue, 2010 [14], who states: work motivation must be seen as a condition in an organization where employees know what is expected by them in terms of organizational rules, standards and policies, and what are the consequences of the violation. The findings of this study also support the research conducted by Ali Sougui O., et. al., 2017 [15], which concludes that "as a leader you must have the power and influence over others to make them behave within the organizations standards, and motivate them to do what is expected and instructed for them to do. Meanwhile, all leadership styles have a significant (positive or negative) on the mployees' motivation, satisfaction and performance. Leadership is more likely to create an atmosphere of motivation among its employees". Based on the description, there is a direct positive effect of leadership style on work motivation

\section{Conclusions}

Based on the analysis results of the variables of leadership style, work motivation and work productivity, it can be concluded as follows; (1) leadership style has a direct positive effect on work productivity, meaning that the leadership style that suits the needs will have a direct impact on increasing work productivity, (2) work motivation has a direct positive effect on work productivity. This means that the improvement and the 
enhancement of work motivation will have a direct impact on the enhancement of work productivity, (3) leadership style has a direct positive effect on work motivation, meaning that the improvement in leadership style will have a direct impact on the improvement of work motivation

\section{REFERENCES}

[1] A. Parluangan, P. B. M, and Y. Soesatyo, "Effect of Leadership Styles, Organizational Climate and Ethos of Work on Employee Productivity (PT. HP Metals Indonesia the Powder Coating)," Int. Journa; 1 Bus. Manag., vol. 11, no. 2, 2016.

[2] Chukwuma and O. Okafor, "Effect of Motivation on Employee Productivity: A Study of Manufacturing Companies in Nnewi," Int. J. Manag. Stud. Res., vol. 2, no. 7, 2014.

[3] S. Hellrigel, Fundamentals of Organizational Behavior. United State: Thomshom South-Western, 2007.

[4] S. G. Isaksen and K. J. Lauer, The Relationship Between Cognitive Style and Individual Psychological Climate: Reflections On a Previous Study. New York: Creative Problem Solving Group, 1998.

[5] Girffin and Moorhead, Organization Behavior, Managing People and Organization. Canada: South-Western, 2010.

[6] Gibson, Ivancevich, Donnely, and Konopaske, Organizations, Behavior Structure Proceses; Organizational Behavior, Human Behavior at Work. New York: McGraw-Hill Education, 2007.

[7] S. P. Robbins and M. Coulter, Management. New Jersey: Pearson Education. Inc., 2012.

[8] Phillips and Gully, Organizational Behavior, Tools for Success. USA: South-Western Cengage Learning, 2012.

[9] S. P. Robbins and T. A. Judge, Organizational Behavior, Fifteenth. England: Pearson Education Limited, 2013.

[10] D. Currie, Personnel in Practice for The New IPD-CPD. Australia: Blackwell Publishing, 1997.

[11] R. E. Clark, Fostering The Work Motivation of Individuals and Teams. California: Clark, R.E, 2003.

[12] L. R. Gay, G. E. Mills, and P. Airasian, Educational Research Competencies for Analysis and Applications, Tenth Edit. USA: Pearson Education. Inc., 2011.

[13] R. Kleinwort, T. Semm, P. M. Falger, and M. F. Zaeh, "Integration of an Android Application into the Learning Factory for Integration an Android into the Learning Factory for Manufacturing of Optimized Machining," Procedia Manuf., no. 2017, 2018.

[14] L. W. Rue and L. L. Byars, Supervision, Key Link to Productivity, Tenth Edit. New York: McGraw-Hill Education, 2010.

[15] A. orozi Sougui, A. T. bin Bon, M. A. Mahamat, and H. M.
H. Hassan, "The Impact of Leadership on Employee Motivation in Malaysian Telecommunication Sector," Galore Int. J. Appl. Sci. Humanit., vol. 1, no. 1, pp. 59-68, 2016.

[16] Janjua Najam, "Impact of Personality Type on Job Productivity, "Journal of Hotel \& Business Management, vol.5, issue 1, p. 2,2016

[17] Zaenal E. Mustafa, Dewi W. Tri Wijayati, and Priyono, "The Influence of Motivation and Discipline Work against Employee Work Productivity Tona'an Markets, "Review of European Studies, vol. 7, no. 12, p. 61, 2015.

[18] Howard J. Klein, An Integrated Control Theory Model of Work Motivation. USA: Ohio State University, 1989.

[19] Interview Result with supervisor coodinator of all State Junior High Schools of Surakarta in June 3rd 2019 